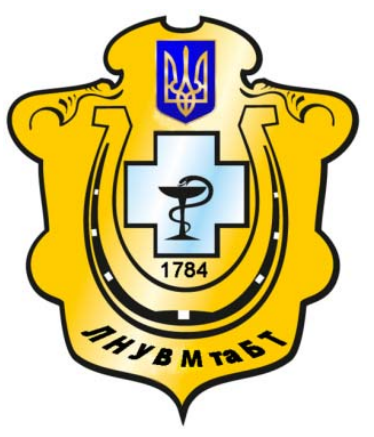

Науковий вісник Львівського національного університету ветеринарної медицини та біотехнологій імені С.3. Гжицького

Scientific Messenger of Lviv National University of Veterinary Medicine and Biotechnologies named after S.Z. Gzhytskyj

doi:10.15421/nvlvet7111

ISSN 2413-5550 print

ISSN 2518-1327 online

$\underline{\text { http://nvlvet.com.ua/ }}$

УДК 619:616.98:628.513

\title{
Епізоотологічний моніторинг сказу тварин у Львівській області за 2014-2016 роки, аналіз проведених антирабічних заходів
}

\author{
Д.М. Левківський, Н.Д. Левківська, Ю.Г. Сторчак, Гутий Б.В. \\ nlevkivska@gmail.com,bvh@ukr.net
}

\begin{abstract}
Львівський наџіональний університет ветеринарної медицини та біотехнологій імені С.3. Гжицького, вул. Пекарська, 50, м. Львів, 79010, Україна
\end{abstract}

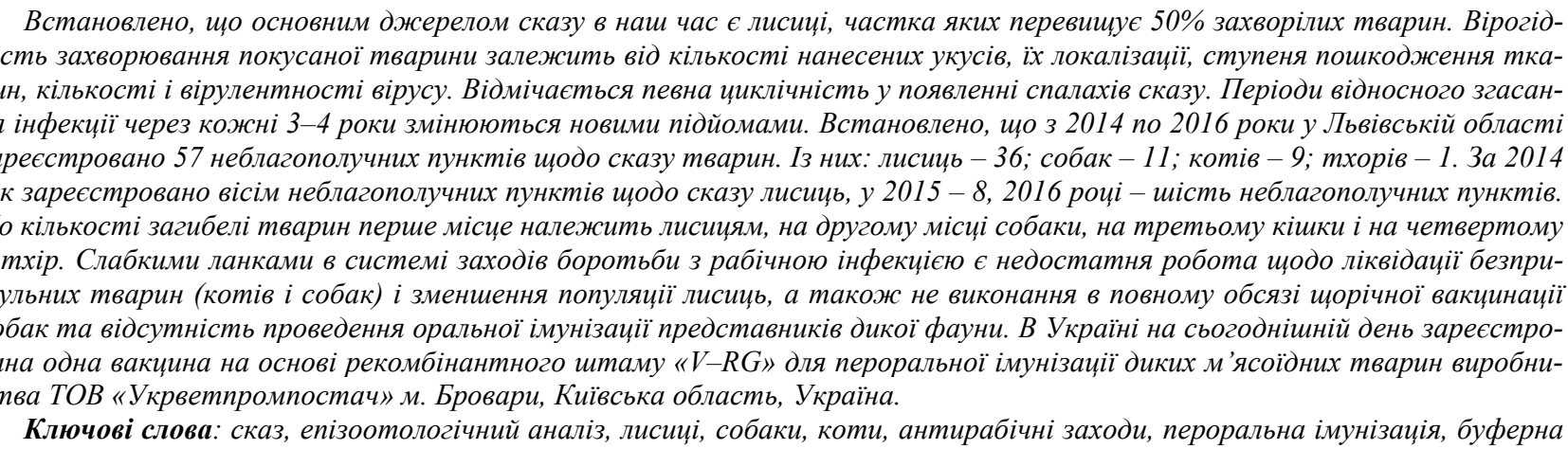
зона.

\section{Эпизоотологический мониторинг бешенства животных во Львовской области за 2014-2016 г., анализ проведенных антирабических мероприятий}

\author{
Д.М. Левкивский, Н.Д. Левкивская, Ю.Г. Сторчак, Б.В. Гутый \\ nlevkivska@gmail.com,bvh@ukr.net
}

\begin{abstract}
Львовский начиональный университет ветеринарной медицины и биотехнологий имени С.3. Гжищкого, ул. Пекарская, 50, г. Львов, 79010, Украина
\end{abstract}

\begin{abstract}
Установлено, что основным источником бешенства в наше время являются лисы, доля которых превышает 50\% заболевиих животных. Вероятность заболевания покусанной животного зависит от количества нанесенных укусов, их локализации, степени повреждения тканей, количества и вирулентности вируса. Отмечается определенная иикличность в появлении вспышек бешенства. Периоды относительного затухания инфекиии через каждые 3 - 4 года сменяются новыми подъемами. Установлено, что с 2014 по 2016 годы во Львовской области зарегистрировано 57 неблагополучных пунктов по бешенству животных. Из них: лис - 36; собак - 11; котов - 9; хорьков - 1. По 2014 зарегистрировано восемь неблагополучных пунктов по бешенству лисии, в 2015 - 8, 2016 году - шесть неблагополучных пунктов. По количеству гибели животных первое место принадлежит лисам, на втором месте собаки, на третьем кошки и на четвертом - хорек. Слабыми звеньями в системе мер борьбы с рабического инфекцией является недостаточная работа по ликвидации бездомных животных (кошек и собак) и уменьшение популяции лис, а также невыполнение в полном объеме ежегодной вакцинации собак
\end{abstract}

Citation:

Levkivsky, D.M., Levkivska, N.D., Storchak, Yu., Gutyj, B.V. (2016). Epizootological monitoring of animal rabies in the Lviv region for 2014-2016, the analysis of rabies events. Scientific Messenger LNUVMBT named after S.Z. Gzhytskyj, 18, 3(71), 50-53. 
и отсутствие проведения оральной иммунизачии представителей дикой фауны. В Украине на сегодняиний день зарегистрировано одна вакцина на основе рекомбинантного штамма «V-RG» для пероральной иммунизации диких плотоядньх животных прочзводства ООО «Укрветпромпостач» г. Бровары, Киевская область, Украина.

Ключевые слова: бешенство, эпизоотологический анализ, лисы, собаки, кошки, антирабические мероприятия, пероральная иммунизация, буферная зона.

\title{
Epizootological monitoring of animal rabies in the Lviv region for 2014-2016, the analysis of rabies events
}

\author{
D.M. Levkivsky, N.D. Levkivska, Yu. Storchak, B.V. Gutyj \\ nlevkivska@gmail.com,bvh@ukr.net \\ Lviv National University of Veterinary Medicine and Biotechnologies named after S.Z. Gzhytskyj, \\ Pekarska Str., 50, Lviv, 79010, Ukraine
}

\begin{abstract}
It was found that the main source of rabies in our time are the foxes, the share of which exceeds $50 \%$ of the diseased animals. Probability bitten animal diseases depends on the number of supported bites, their location, extent of tissue damage, and amount of virus virulence. It notes some cyclicality in the emergence of rabies outbreaks. Periods of relative attenuation of infection are replaced with new lifts every 3 - 4 years. It was found that durig the period from 2014 to 2016 it was registered 57 unfavorable items rabies animals in the Lviv region. Among them: the fox-36; dogs-11; cats - 9; ferrets - 1. In 2014 eight disadvantaged areas with rabies foxes has been recorded, in 2015-8,2016 - six disadvantaged areas. By the number of animal deaths the first place belongs to the foxes, the second dog place on the third and fourth cat-ferret. The weak link in the system of measures to combat rabies infection is the lack of work on the elimination of stray animals (dogs and cats) and a decrease in the population of foxes, as well as the failure to implement fully the annual vaccination of dogs and lack of oral immunization of wildlife species. Today a vaccine based on a recombinant strain « $V-R G »$ for the oral immunization of wild carnivores registered in Ukraine, which is produced by LLC «Ukrvetprompostach», Brovary, Kiev region, Ukraine.
\end{abstract}

Key words: rabies, epizootological analysis, foxes, dogs, cats, rabies measures oral immunization buffer zone.

\section{Вступ}

Сказ - особливо небезпечне, гостре антропозоонозне захворювання, що викликається специфічним нейротропним вірусом і характеризується глибокими ураженнями центральної нервової системи. Дане захворювання потребує особливої уваги фахівців ветеринарної й медичної науки, оскільки, в багатьох областях України займає чільне місце в інфекційній патології. Щорічні спалахи хвороби не припиняються як серед диких м'ясоїдних, так і серед сільськогосподарських та домашніх тварин, особливо кішок та собак. У підсумку це зумовлює складну епізоотологічну й епідемічну ситуації та необхідність проведення комплексних заходів боротьби, включаючи і пероральну імунізацію диких тварин в епізоотичних природних вогнищах.

Актуальність теми. На сьогодні в Україні, незважаючи на відомі досягнення в профілактиці особливо небезпечних інфекційних хвороб тварин (сибірка, туберкульоз, лейкози, бруцельоз, чума тощо), спалахи сказу не припиняються серед диких м'ясоїдних, кішок та собак, великої й дрібної рогатої худоби. Разом 3 тим, це зумовлює захворюваність людей і потребує координованих зусиль ветеринарних, медичних і інших фахівців, зацікавлених у вирішенні проблеми сказу.

В Україні в минулому основними розповсюджувачами сказу були собаки. У 1966 р. спостерігалось залучення до епізоотичного процесу диких тварин, насамперед лисиць (Bozhko et al., 1981; Emel'janov, 1983). В 2000 р. в 24 країнах Свропи від сказу загинуло 9735 тварин, переважно, в східноєвропейських країнах. С країни, де, завдяки реалізації програми оральної імунізації лисів, сказу немає. Це Італія, Швейцарія, Франція, Бельгія, Нідерланди, Австрія. Найбільша кількість захворілих на сказ тварин - в Польщі - 2211 випадків, на 2-му місті в Свропі - 1580 випадків - Україна, де епізоотія сказу природного типу триває більше 30 років. Вогнища сказу реєструються у всіх областях і природно-географічних зонах України. В 2003-2013 роках найбільш ураженими на сказ були Чернігівська, Луганська, Полтавська, Черкаська, Харківська області, на які прийшлося понад 62\% всіх випадків сказу тварин.

Встановлено, що основним джерелом збудника інфекції в наш час $є$ лисиці, частка яких перевищує $50 \%$ захворілих тварин (Kovalev and Davydenko, 1986).

Напруженість епізоотичної ситуації на даний час визначається наявністю природних вогнищ хвороби, особливо серед диких м'ясоїдних. Виходячи з епізоотичних даних, як правило, в усіх випадках свійські тварини заражаються від диких хижаків (вовки, лисиці). Вірогідність захворювання покусаної тварини залежить від кількості нанесених укусів, їх локалізації, ступеня пошкодження тканин, кількості і вірулентності вірусу (Alimov and Ugrjumov, 1982; Alimov, 1984).

Ковальов Н.А. відмітив, що періодичність епізоотій сказу, є характерною особливістю хвороби і що відмічається певна циклічність у появленні спалахів сказу. Періоди відносного згасання інфекції через кожні 3-4 роки змінюються новими підйомами (Kovalev and Davydenko, 1986).

Сезонами максимального розповсюдження «міського» сказу є весна та літо. При сказі диких тварин сезонні коливання інтенсивності епізоотичного про- 
цесу мають інший характер. Найменша кількість хворих відмічається у червні-серпні, а найбільша у березні та у жовтні-грудні (Laptev, 2006).

Мета $i$ завдання досліджень. Враховуючи актуальність епізоотичного благополуччя України у відношенні сказу, в основі якого, в першу чергу, лежить комплекс антирабічних заходів, та тривале неблагополуччя Львівської області у відношенні до цієї хвороби, метою наших досліджень було провести епізоотологічний моніторинг по сказу у Львівській області, встановити закономірності виникнення захворювання відповідно до пори року, піки епізоотії і згасання, а також проаналізувати комплекс антирабічних заходів в області.

\section{Матеріал і методи досліджень}

Матеріалами досліджень були: акти епізоотологічних обстежень неблагополучних щодо сказу пунктів; річні звіти управлінь безпечності харчових продуктів та ветеринарії районів; статистичні дані Головного управління Держпродспоживслужби області; річні звіти Львівської регіональної державної лабораторії ветеринарної медицини, супровідні документи та матеріали первинного ветеринарного обліку; статистичні дані державних управлінь лісового господарства у Львівській області; статистичні дані Управління державного нагляду за дотриманням санітарного законодавства у Львівській області.

\section{Результати та їх обговорення}

За результатами епізоотичного моніторингу та аналізу звітної документації було встановлено, що 3 2014 по 2016 роки у Львівській області зареєстровано 57 неблагополучних пунктів щодо сказу тварин. Із них: лисиць - 36 (63,16\%); собак - 11 (19,30\%); котів - $9(15,79 \%)$; тхорів - $1(1,75 \%)$.

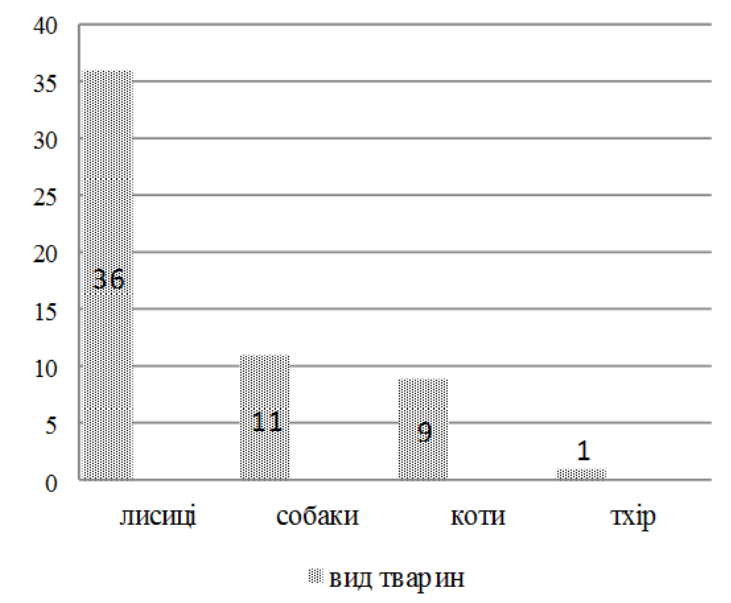

Рис. 1. Динаміка виявлення сказу у Львівській області (за 2014-2016 роки)

За 2014 рік зареєстровано вісім неблагополучних пунктів щодо сказу лисиць у Бродівському, Буському, Городоцькому, Жовківському, Золочівському, Ско- лівському, Сокальському та Стрийському районах Львівської області (10 випадків).

За 2015 рік зареєстровано вісім неблагополучних пунктів щодо сказу лисиць у Бродівському, Буському, Жовківському, Кам'янка-Бузькому, Пустомитівському, Сколівському, Сокальському та Стрийському районах Львівської області (17 випадків).

За період з січня по вересень 2016 року було зареєстровано шість неблагополучних пунктів щодо сказу лисиць у Буському, Городоцькому, Жидачівському, Жовківському, Кам'янка-Бузькому та Пустомитівському районах Львівської області (9 випадків).

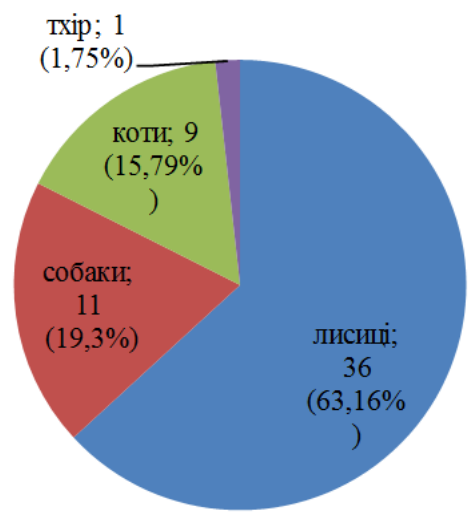

Рис. 2. Захворюваність на сказ по видах тварин за 2014-2016 роки

За даними М.Г. Таршиса, І.П. Арутюнової (Tarshis et al., 1990; Arutjunova, 1999) сезонні коливання сказу збігаються з періодом гону лисиць. У літній період, коли лисиці зайняті вихованням виводків і рухливість їх обмежена, число захворювань мінімальне. Восени, в результаті збільшення щільності популяції за рахунок молодих особин, спостерігається нове зростання рівня захворювання.

Матеріали, подані в актах епізоотичних обстежень неблагополучних щодо сказу господарств засвідчують, що головною ознакою хвороби у диких тварин були зміни в поведінці, втрата у них інстинкту самозахисту. Звірі з'являлись вдень у населених пунктах, в місцях випасу сільськогосподарських тварин та їх утримання. Вони без страху нападали на людей і тварин. Людям навіть вдавалося піймати лисиць руками. При цьому спостерігали численні випадки нанесення укусів людям і тваринам.

Аналізуючи співвідношення видів тварин в етіології сказу слід зазначити, що по кількості загибелі тварин перше місце належить лисицям, на другому місці собаки, на третьому кішки і на четвертому - тхір.

Останнім часом, досить різко зросла епізоотична роль кішок у захворюванні на сказ тварин і людей. Це пояснюється відсутністю у них імунітету, спільними для інших хижаків місцями полювання, схильністю до бродяжництва та зростанням чисельності бродячих тварин. Відзначається пряма залежність між захворюваністю у лисиць і бродячих кішок. Заражаючись від лисиць у природних вогнищах, кішки стають активними постачальниками вірулентних штамів вірусу сказу у населені пункти і на тваринницькі ферми. 
Аналізуючи структуру захворюваності тварин на сказ у Львівській області та враховуючи кількість випадків захворювання м'ясоїдних i синантропних тварин, вважаємо, що існують передумови виникнення перехідних або змішаних вогнищ - природноантропургічних, основними причинами цього є: синантропізація диких тварин та здичавіння домашніх котів та собак, залишених господарями.

Поряд з основним джерелом збудника сказу - лисиць, підвищується роль собак, котів, тхорів в епізоотичному процесі.

За останні роки в Львівській області намітилось динамічне збільшення кількості неблагополучних пунктів та захворілих в них на сказ тварин.

Слабкими ланками в системі заходів боротьби 3 рабічною інфекцією є недостатня робота щодо ліквідації безпритульних тварин (котів і собак) і зменшення популяції лисиць, а також не виконання в повному обсязі щорічної вакцинації собак та відсутність проведення оральної імунізації представників дикої фауни

Пероральна імунізація диких тварин в Львівській області проводиться 32012 р. відповідно до Угоди між Міністерством аграрної політики та продовольства України та Міністерства сільського господарства i розвитку села Республіки Польща (http://vet.gov.ua/node/2525).

3 метою захисту території Свросоюзу від поширення вірусу сказу і Республіки Польща була визначена 70 км буферна зона, в яку входять 13 районів: Городоцький, Дрогобицький, Жовківський, КамянкаБузький, Мостиський, Пустомитівський, Радехівський, Самбірський, Сколівський, Сокальський, СтароСамбірський, Турківський, Яворівський. Була вирахувана площа території цих районів, яка підлягала пероральній імунізації - 12,7 тис. км. Зроблено розрахунки необхідної кількості вакцини для пероральної вакцинації (317,5 тис. доз, з розрахунку 25 приманок на $\left.1 \mathrm{KM}^{2}\right)$.

В кожному районі були визначені контрольні ділянки для обліку споживання вакцини на 4, 8, 15-й день після розкладання вакцини. Вакцина розкладалася спеціалістами державної ветеринарної медицини разом $з$ представниками лісового господарства.

Перед початком проведення компанії пероральної вакцинації в області ГУВМ проводилися тендерні торги по питаннях закупівлі вакцини антирабічної «Броварабіс V-RG» 3 дотриманням необхідних процедур закупівлі.

В Україні на сьогоднішній день зареєстрована одна вакцина на основі рекомбінантного штаму «V-RG» для пероральної імунізації диких м’ясоїдних тварин виробництва ТОВ «Укрветпромпостач» м. Бровари, Київська область, Україна.

Через місяць після проведення пероральної осінньої вакцинації проводиться відстріл лисиць з вакцинованої території. У відстріляних лисиць відбиралися нижні щелепи для дослідження зубів на наявність тетрацикліну та зразки крові на наявність вірус нейтралізуючих антитіл.

\section{Висновки}

По кількості загибелі тварин перше місце належить лисицям, на другому місці собаки, на третьому кішки і на четвертому - тхір. Слабкими ланками в системі заходів боротьби з рабічною інфекцією $є$ недостатня робота щодо ліквідації безпритульних тварин (котів і собак) і зменшення популяції лисиць, а також невиконання в повному обсязі щорічної вакцинації собак та відсутність проведення оральної імунізації представників дикої фауни

Побажання: Для покращення епізоотичної ситуації по сказу серед диких тварин необхідно проводити пероральну вакцинацію на території всієї області (20 районів).

\section{Бібліографічні посилання}

Bozhko, G.K., Grishak, L.P., Sinicyn, A.Ju. (1981). Beshenstvo dikih zhivotnyh. K.: Urozhaj (in Russian). Emel'janov, B.M. (1983). Rasprostranenie, klinika i profilaktika beshenstva v USSR. Veterinarija. 4, 5963 (in Russian).

Kovalev, N.A., Davydenko, V.P. (1986). Profilaktika beshenstva. Krolikovodstvo i zverovodstvo. M. Agropromizdat. 5, 24 (in Russian).

Alimov, D.M. (1984). Beshenstvo zhivotnyh. M., 20-29 (in Russian).

Alimov, D.M., Ugrjumov, V.I. (1982). Voprosy patogeneza beshenstva. Kn. Diagnostika zaraznih zabolevanij sel'skohozjajstvennyh zhivotnyh. Kazan', 60-62 (in Russian).

Laptev, O.G. (2006). Patomorfologija virusa beshenstva. Veterinarija. 12, 10 (in Russian).

Arutjunova, I.P. (1999). Sezonnost' projavlenija beshenstva zhivotnyh v Kurskoj oblasti. Agrarnij visnik Prichornomor'ja: Veterinarni nauki. 2(7), 87-90 (in Russian).

Tarshis, M.G., Kovalev, N.A., Kuznecov, P.P. (1990). Beshenstvo zhivotnyh. Minsk: Uradzhaj (in Russian). http://vet.gov.ua/node/2525.

Стаття надійшла до редакиії 1.10.2016 